\title{
GENDER IDENTIFICATION OF THE BRITISH NEWS TEXT
}

\author{
Tatyana N. Astafurova \\ Volgograd State University, Volgograd, Russian Federation \\ Elena S. Aleksandrova \\ Volgograd State University, Volgograd, Russian Federation
}

\begin{abstract}
The article is devoted to studying the impact of gender on speech behavior in mass media discourse. Gender peculiarities of English news text-formation are examined through coordination of various language means that belong to different levels of the language system with predetermined socio-cultural factors and psychological peculiarities attributed to man as a representative of masculine subculture, a communicative leader, characterized by autonomous thinking, logic, rationality, objectivity, lingua-creativity, reduced emotionality, and woman as a representative of feminine subculture, characterized by a greater degree of emotionality, empathy, cooperativeness. A number of gender parameters is listed, including content and structural features, specification / generalization of information, stylistically neutral / marked vocabulary etc. These parameters are being viewed as related with the categories of informativeness and expressiveness.

It is determined that the features of the news text on the structural level manifest themselves in the selection of aspects of the events described, the organization of informative blocks. On the stylistic level gender specificity is expressed by linguistic realization of emotionality, evaluation, imagery. Gender parameters of the news text determine masculine and feminine styles of news text-formation and are included in the developed matrix of gender identification of the author of the news text. The psycholinguistic experiment allowed to verify the validity of gender parameters of the news text and to establish that the degree of sensitivity to its gender characteristics is determined by socio-cultural differences of native and non-native speakers of English.

Key words: gender linguistics, news text, mass-media discourse, information structure, stylistic devices, expressiveness.
\end{abstract}

\section{ГЕНДЕРНАЯ ИДЕНТИФИКАЦИЯ БРИТАНСКОГО НОВОСТНОГО ТЕКСТА}

\author{
Татьяна Николаевна Астафурова \\ Волгоградский государственный университет, г. Волгоград, Российская Федерация \\ Елена Сергеевна Александрова \\ Волгоградский государственный университет, г. Волгоград, Российская Федерация
}

\footnotetext{
Аннотация. Статья посвящена изучению влияния гендерного фактора на речевое поведение участников массово-информационного дискурса. В работе рассматриваются гендерные особенности новостного текстопорождения на английском языке, обусловленные социокультурными и психологическими признаками, приписываемыми социумом мужчине как представителю маскулинной субкультуры, коммуникативному лидеру, отличающемуся автономным мышлением, логичностью, рациональностью, объективностью, лингвокреативной компетенцией, меньшей степенью эмоциональности, и женщине - как представителю феминной субкультуры, отличающемуся большей степенью эмоциональности, эмпатии, кооперативности.

Установлено, что идентификации гендерных параметров новостного текста (содержательно-структурная специфика, конкретизация / генерализация информации, стилистически нейтральная / маркированная лексика и др.) соотносима с проявлениями категории информативности и экспрессивности.
} 
Определено, что специфика порождения новостного текста гендерно-нейтральной тематики на содержательно-структурном уровне отражается в отборе аспектов описываемого события, структурации информативных блоков, использовании способов конкретизации / генерализации информации fe/male авторами; на стилистическом уровне - в лингвистических способах реализации эмоциональности, оценочности, образности. Психолингвистический эксперимент позволил верифицировать валидность гендерных параметров новостного текста, а также установить, что степень восприимчивости к гендерным особенностям новостного текста детерминируется межкультурными различиями носителей и неносителей английского языка.

Ключевые слова: гендерная линвистика, новостной текст, масс-медийный дискурс, информационная структура, стилистические приемы, экспрессивность.

\section{1}

In the past decades gender studies have become popular in linguistics, and focus not so much on biological characteristics of a person, but rather on the features, determined by social factors and reflected in lingua-cultural behavior of an individual.

Russian and foreign linguists investigate spoken and written language of various professional, ethnic and age groups, generating a representative range of works devoted to various aspects of the relationship between language and gender. These include studies of speeches of Afro-American women in Chicago [10], characteristics of the communicative behavior of the police (men and women) [9], communication strategies of fe/male Internet users [6], the thematic specificity of everyday discourse of the white middle class [5], etc. Russian linguistics examines gender markers of verbal behavior of political leaders [13], verbal fe/male behavior in informal communicative situations [8], gender nominative specificity of the poetic text [1], verbalization of emotions in artistic prose [2], etc.

Gender differences in language and speech point to gender stereotypes, that are determined by social roles of men and women and affect gender identity in accordance with socio-cultural attitudes, norms and rules of a given society. The basis of the gender stereotype formation constitutes the notions of femininity and masculinity, which have undergone major changes, reflected in the discrepancy of biological sex and psychological manifestations of gender. The analysis of international gender studies shows that in modern societies women who have attained high professional status, as a rule, demonstrate more masculine features than their male counterparts, modern men "have no taboo on emotions, greater emotional openness and performance of traditionally female work" [15]. Thus, masculinity and femininity are probably not the opposites but dialectically related categories, reflecting social processes which change parameters of masculinity (aggression, arrogance, dominance, independence, decisiveness, determination) and femininity (emotionality, care, friendliness, courtesy, kindness). However, as the study showed, despite the blurring of boundaries between masculinity and femininity, the news texts are still gender marked.

Research in the field of feminist and masculine linguistics has shown gender specificity in the content, punctuation, spelling, syntax, lexicophraseology and stylistics of the news texts, which allows to select the following parameters of masculine and feminine styles of text-formation:

- thematic (prior women's issues - family, health, education, men's - politics, science, sport, profession);

- communicative-pragmatic (female communicative behavior is characterized by cooperative strategies, indirect and fatual speech acts, empathy, communicative flexibility, delegation of responsibility; male communicative behavior - by competitive strategies, communicative leadership, imperative speech acts, authoritarianism);

- syntax (female syntax is characterized by subordinate bonds, exclamatory and interrogative sentences, passive, elliptical and inverted structures, male syntax - by coordinative ties, active structures);

- stylistics (female style is characterized by hyperbolizing, expressiveness, intensification of positive evaluation, concentration of emotionalevaluative lexis, diminutive suffixes; male styleby concentration of professional terminology, stylistically neutral and emotionally negative vocabulary, invectives).

The highlighted parameters of $f e / m a l e$ styles of text-formation have become verbal stereotypes 
that underlie gender identification of the author of the text, news text, the gender specificity of which was under investigation including.

\section{2}

The pragmatic function of the news text as a genre of mass-media discourse [7] is to inform readers about events happening in the real world, so news information determines the structural organization of the text. The study revealed that publications of this genre include not only the factual description of events, but also elements of evaluation, forecasting, commenting on possible consequences of the event [14]. Thematic focus of the news text, according to the results of our psycholinguistic experiment, is the determining parameter of gender markedness, due to stereotypical notions of media influence, traditionally attached to fe/male journalists. A thematic analysis of preferences of fe/male authors in the British press helped to clarify topics, covered by male authors (sports, politics, economics, business, science); and fe/male writers (fashion, social protection, health, education, culture).

During the first phase of the experiment 40 informants (20 men and 20 women), among them 14 native speakers of English from Great Britain, the USA at the age of 29-45 years and 26 students from Malaysia, at the age of 19-25 years, almost correctly determined the gender of the author of the texts by its thematic orientation. The aim of the second phase of the experiment was to verify the validity of the remaining options of the gender identification of the author of the text. In this regard we selected news texts of genderneutral topics (400,000 signs), namely, texts about natural disasters (hurricanes, earthquakes, landslides, typhoons, tsunamis), presented in equal quantity by fe/male authors (the sex of the author was specified in the online sources), but in different ways. The analysis of these news texts revealed that differences manifest themselves in the variability of substantive aspects of the events described, the structuration of informative units, lexico-stylistic ways event's description.

3

The study of substantive aspects of news texts showed that male authors touch upon political, legal, economic and scientific problems caused by natural disasters on the global scale; news texts, written by male authors are characterized by the use of political (state of emergency, anarchy, foreign donors, anticorruption campaigners, etc.), economic, legal and scientific terms (frozen funds, to issue contracts, contractors, subcontractors, fraud, criminal proceeding, looting, lawlessness, inquest, hearing, coroner, to preside, groundpenetrating radar, electromagnetic waves, underground structures etc.). Female authors mainly refer to personal and social problems of victims of natural disasters that constitute the headlines of news texts: "Katrina's sent by God to punish New Orleans gays"; "This is turning into the ethnic cleansing of New Orleans"; "Asian earthquake victims are missing out on school"; etc. But the leveling of differences in masculine and feminine news texts is manifested in the fact, that along with social aspects of the news event, female journalists often highlight economic, legal and political consequences of the disaster but within a certain social group or a concrete individual: "Brown calls for aid 'shock' fund, Millions pledged for tsunami go unpaid"; "the Laughing stock of Katrina makes disaster his business" etc.

Thus, a substantial aspect of media content is determined by psychological peculiarities of $f e /$ male perception of reality. Men perceive and evaluate the situation as a whole, they are more interested in global integrity, not requiring detailed attention, therefore male authors extrapolate the problems of the country on the world community [12]: "China becomes the world's third largest donor of food", "Hundreds dead or missing in North Korea", "Indonesia faces new megatsunami, Quake devastates Java" etc. Women rather focus attention on details, carefully analyze events of local importance: Britons get fast-track visas, Birmingham University houses tornado victims, Lloyd's fears Rita may bring $\$ 60$ bn. stress test to life etc. A distinctive feature of women's consciousness of information is its concreteness, anthropocentrism and social orientation [12], namely, description of the impact of natural disasters on a particular person / social group. The specificity of the psychological perception of reality by women and men is determined by the peculiarities of gender identity formation in children: in girls gender identification 
runs in close connection with mother, association with her, awareness of the significance of the relationship between people; in boys sexual identity is connected with opposition to mother and the isolation that underlies the formation of independence [3].

The study showed that female authors tend to concretize, specify information, whereas men to generalize it. So, nominating participants of the events male authors often use collective nouns and substantivized adjectives: people, the survivors, the victims, the affected, the injured, female authors specify personal and social features of participants:

- biological parameters and physical / mental state (The poorest and most vulnerable members of the community, such as the elderly and the sick, were worst hit... etc.);

- racial identity (...poor, mostly black citizens of New Orleans begging for food... worst damaged by the storm were AfroAmericans..., etc.);

- personal characteristics and appearance (... pleaded the man in the yellow jacket and blue trousers etc.);

- social and professional status (Alice's mother, who worked as a charity arts officer..., her husband, Michael, a shipbroker... etc.).

Gender peculiarities of the category of informativeness are also revealed in the organization of informative blocks of the texts by fe/male authors: male authors usually follow the truncated scheme of the news text, developed by T. van Dijk: Title, Introduction, the Main event, Comments, History, Reaction, Consequences, Background/Circumstances, i. e. the informative blocks follow a strict logical sequence.

With the deployment of the masculine news text, the reader gets information about the main event, its background and causes, consequences, circumstances, and the broader context of the events arranged in a logical sequence. Female articles often miss such blocks as Background, Circumstances, History, and are often marked by individual variation of informative blocks and their merger. The selective variance of informative blocks in feminine texts is explained by their higher informative significance for female authors and the realization of their communicative intention to emotionally affect the reader, appealing to compassion and empathy.
Emotional involvement of a female author in the above described situation explains reiteration of information about different kinds of consequences of natural disasters, its visualization through the citation of witnesses giving a detailed description of their feelings and emotions, while a male author mostly quotes officials stating dates, names, numbers (precise information). The prevalence of contentfactual information is provided by using place names (... houses in the town of Kalemie, on the shores of Lake Tanganyika in eastern Congo, The hurricane, which left 32 people in Haiti and Cuba dead, arrived in Alabama and northwestern Florida ..., etc.); names of international leaders and foreign organizations, communities, institutions (British International Rescue Dogs, the Department for International Development, the Disaster and Emergency Committee, the Pacific Tsunami Warning Center, the UN children's agency Unicef, etc.), that increases the reader's trust to information.

\section{4}

Gender peculiarities of the category of expressiveness are revealed in realization of emotiveness, evaluation and imagery in the news text. Men's emotionality is evident in emotive nominations of disasters, namely male authors tend to create emotiveness by using barbarisms, that contributes to the emotional impact on the reader (zalzala $=$ earthquake fr. Urdu), its political and economic consequences for the nation (ferocious super-typhoon, earthquake nightmarish, horrendous damage, terrifying economic consequences etc.). Female emotionality lies in the inherent ability to empathize, to show compassion to participants of the event, to recognize and decode non-verbal cues [12] of their psycho-physical and emotional state (clutch, v.: hold something or someone tightly, especially because you are frightened, in pain; distress, v.: make someone feel very upset or worried; sob, v.: cry noisily, taking in deep breaths; rack, v.: experience physical or mental pain; tremble, v.: shake gently with fear; etc - LDCE; suffer, v.: feel pain or sadness; frighten, v.: make someone feel fear; scare, v.: feel worried etc $-C A L D)$.

The expressiveness of the news text is also created with the positive / negative assessment 
of various aspects of the event (its implications and context, the participants and their actions, etc.). Female authors express evaluation of natural disasters mostly by using:

- suffixes of superlative adjectives (the costliest insured natural disaster in the world, the strongest hurricane, one of the deadliest storm seasons in the southern United States, etc.);

- evaluative adjectives (awesome hurricane, devastating earth quake, catastrophic flood etc.).

An equally important component of expressiveness is the imagery created by comparing two denotations on the basis of common characteristic [11]. The main stylistic devices of creating imagery in news texts are personification, metaphor, simile. In the male news texts the disaster gets the signs of personification: The quake convulsion buckled the earth, chewed up buses and levelled practically every building in sight; African children in earthquake buries homes; ...the town has been eaten alive. Gender specificity of creating imagery by fe/male authors is determined by discrepancy of their associative thinking [4], which is based on humanistic essence in women and artifact in men. So, the cities destroyed by the earthquake with concrete roofs collapsed on children male authors compared to gravestones (...the concrete slab roofs of schools across Kashmir and North West Frontier province fell like tombstones entrance, crushing children at their desks), the city where the disaster struck is compared to the place cursed by God (It looks like God has cursed this place), the ruins of the destroyed villages are associated with archaeological ruins (The remains are just visible in the snow, like the site of an archaeological dig). Female authors prefer prolonged and fresh metaphors, associating the flooded city with a sick old man, left to die alone (Like a sickly old patient left out to die, the coastal town...), a tornado that destroyed the resort is compared with the Ghost (But the place, once the epitome of packaged fun, still feels much like a ghost, with windowless high-rises and empty streets).

Stylistic analysis of the news texts showed that men often have higher level of lingua-creative competence, manifested in the use of wider and more varied set of stylistic devices: male authors often use metaphor (Now it is again the valley of death), epithet (stubborn residents, harassed and intimidated girls), parallel structures (There are no food queues, no water tankers, no tents...), comparison (It sounded like there was a jet engine in the backyard), gradation (Memories of that terrible morning last October - when the earth rumbled, buckled and killed more than 87,000 people...), antithesis (They came from all walks of life laborers, office clerks and university lecturers - bringing modest supplies of medicine, food but an abundant promise of help), anadiplosis, anaphora, rhetorical question (Who cares?), oxymoron (But after the rain, Chinese rescuers brought the well-known news). Most frequently used stylistic devices by female authors are epithet, parallelism, comparison, gradation, and anaphora.

The material analyzed also demonstrated differences in the ways fe/male authors refer to citing. Thus, female authors cite witnesses (mostly women) of natural disasters, emotionally describing his / her physical and mental condition, the scope of damage, the depth of grief and loss. Citation of this kind helps to create the effect of presence, appealing more to feelings than rational mind of readers.

Male authors, on the contrary, tend to quote mainly male eyewitnesses of natural disasters, mention their courage and dedication in the struggle with disaster, resilience in overcoming its consequences, i.e. masculine psychological characteristics: So, Declan Walsh quoted a resident of Pakistan, helping the inhabitants of the neighboring destroyed by the earthquake of the village, although he had received severe injuries. Moreover, male authors readily quote the official representatives, giving a rational assessment of the damages caused by natural disaster, financial assistance allocated by the government and donor countries, compensation to the victims of the tragic events.

\section{5}

Thus, gender parameters of the news text revealed allow differentiating masculine and feminine styles of text-formation and suppose that they are included in the developed matrix of gender identification of the author of the news 
text. The validity of the selected gender parameters of the news text was confirmed at the second stage of analysis, that was the psycholinguistic experiment in which the participants were asked to read 6 news texts of gender-neutral topics with the aims to identify their fe/male authors and then verify the parameters of masculine and feminine news text-formation.

The original language material of the experiment was represented in 6 news texts on natural disasters (a gender-neutral topic) from The Guardian and the Times (UK). The analysis of the participants' responses on the first question showed that in the group of native English speakers the author's gender was correctly identified by $84 \%$ of men and $79 \%$ of women, whereas in the group of non-native English speakers $75 \%$ of the male informants and $3 \%$ of female informants managed to correctly identify the author's gender. A small percentage of nonnative English speakers who managed to identify the author's gender may be explained by differences in socio- and lingua-cultural competence. The US and UK, seeking to obtain the status of a society with gender equality and political correctness, actively introduce the issues of gender equality in linguistic and socio-cultural paradigms, widely present them in the media, which explains the higher percentage of correct identification of fe/male gender of news texts' authors. However, Malaysia is a Muslim country, in which Oriental values are opposed to Western and imply gender discrimination of women in all spheres of social life, unequal access to information by women and men, which explains the low susceptibility of students from Malaysia to gender differences in masculine and feminine styles of text formation.

Most informants noted that news texts written by male authors are characterized by a wide usage of terms, stylistically neutral vocabulary, precise information and its generalization, citing of official sources. Only $15 \%$ of informants highlighted the emotional and evaluative vocabulary as a parameter of the text written by male author. Most nonEnglish speakers noted that news texts written by female authors are characterized by emotive, evaluative and figurative language, specific and detailed information, citation of victims of a disaster.

\section{6}

Thus, gender specificity of news texts is determined by socio-cultural factors and psychological peculiarities attributed to man as a representative of masculine subculture, a communicative leader, characterized by autonomous thinking, logic, rationality, objectivity, lingua-creativity, reduced emotionality, and woman as a representative of feminine subculture, characterized by a greater degree of emotionality, empathy, cooperativeness. It is linguistically manifested in gender parameters of the news text and verified in content and structural specificity, stylistically neutral / marked vocabulary, specification/generalization of information strategies, as well as in the selection of events description aspects, informative blocks structuring, ways of event description styles. The psycholinguistic experiment proved the validity of the allocated gender options of news texts on structural and lingua-stylistic levels, revealed the dependence of susceptibility of informants to gender characteristics of news texts due to national and socio-cultural stereotypes.

\section{REFERENCES}

1. Babenkova E.A. Gendernaya paradigma angloyazychnogo poeticheskogo teksta [The Gender Paradigm of English Poetic Text]. Traditsii inovatorstvov gumanitarnykh issledovaniyakh: sb. nauch. tr., posvyashch. 50-letiyuf-ta inostr. yaz. Mordov. gos. un-ta im. N.P. Ogareva [Tradition and Innovation in Humanitarian Studies: Collected Scientific Works Dedicated to the 50th Anniversary of the Faculty of Foreign Languages of Mordovia State Institutenamed after N.P. Ogarev]. Saransk, Izd-vo Mordov. un-ta, 2002, pp. 173-175.

2. Bazhenova I.S. Ekspressiya emotsiy v kontekste gendernykh issledovaniy [Expression of Emotions in the Context of Gender Studies]. Traditsii $i$ novatorstvo $v$ gumanitarnykh issledovaniyakh: $s b$. nauch. st. po materialam dokladov $i$ soobshcheniy konferentsii. Chast 4. Slovo v tekste [Tradition and Innovation in Humanitarian Studies: Collected Scientific Works Based on Conference Reports. Part 4. The Word in the Text]. Smolensk, SGPU Publ., 2001, pp. 99-104.

3. Gilligan C. In a different voice: Psychological theory of women's development. Cambridge, MA, Harvard University Press, $1982.184 \mathrm{p}$.

4. Goroshko E.I. Gendernaya problematika v yazykoznanii [Gender Issues in Linguistics]. Vvedeniev gendernye issledovaniya: $v 2 \mathrm{ch}$. Ch. 1 [Introduction to Gender Studies. In 2 parts. Part 1]. Kharkov; Saint Petersburg, HUGI Publ., Aleteya Publ., 2001, pp. 508-542. 
5. Greenwood A. Gender Management and Power Strategies in Adolescent Conversation. Bergvall V., Bing J., Freed A., eds. Rethinking Language and Gender Research: Theory and Practice. London, Essex, 1996, pp. 77-97.

6. Herring S., Johnson D. "This Discussion Is going Too Far!" Male Resistance to Female Participation on the Internet. Hall K., Bucholtz M., eds. Gender Articulated: Language and the Socially Constructed Self. N.Y., Routledge, 1995, pp. 67-96.

7. Kim M.N. Zhanry sovremennoy zhurnalistiki [Genres of Modern Journalism]. Saint Petersburg, Izdvo Mikhaylova V.A., 2004. 335 p.

8. Martynyuk A.P., Zemlyanskiy P.N. Rechevoe povedenie muzhchin i zhenshhin $\mathrm{V}$ neformalnoy kommunikativnoy situatsii [Speech Behavior of Men and Women in the Informal Communicative Situation]. Pol i ego markirovka v rechevoy deyatelnosti [Gender and Its Labeling in Speech]. Krivoy Rog, MIC CHYAKP Publ., 1996, pp. 114-126.

9. McElhinny B. Challenging Hegemonic Masculinities: Female and Male Police Officers Handling Domestic Violence. Hall K., Bucholtz M., eds. Gender Articulated: Language and the Socially Constructed Self. N.Y., Routledge, 1995, pp. 215-243.

10. Morgan M. Indirectness and Interpretation in African American omen's Discourse. Pragmatics, 1991, no. 1, pp. 421-452.

11. Samsonova E.V. Natsionalno-kulturnyy komponent ekspressivnosti (v yazyke avstraliyskoy khudozhestvennoy prozy): avtoref. dis. ... kand. filol. nauk [National-Cultural Component of Expressiveness (in the Language of Australian Fiction). Cand. philol. sci. abs. diss.]. Moscow, 2000. 23 p.
12. Sheynov V.P. Muzhchina i zhenshchina [Man and Woman]. Entsiklopediya vzaimootnosheniy [Relationships Encyclopedia]. Saint Petersburg, Kurs Publ., 1997. 639 p.

13. Talina I.V. Predposylki vozniknoveniya gendernogo podkhoda $\mathrm{v}$ pedagogike [Prerequisites of Emergence of Gender Approach in Pedagogics]. Vestnik Kazanskogo tekhnologicheskogo universiteta, 2009, no. 4, pp. 332-337.

14. Tertychniy A.A. Zhanry periodicheskoy pechati [Genres of the Periodicals]. Moscow, Aspekt Press, 2001.351 p.

15. Zdravomyslova E.A., Temkina A.A. Vvedenie. Feministskiy perevod: tekst, avtor, diskurs [Feminist Translation: Text, Author, Discourse]. Khrestomatiya feministskikh tekstov [Anthology of Feminist Texts]. Saint Petersburg, Izd-vo Dmitriy Bulanin, 2000. 303 p.

\section{SOURCES}

$C A L D$ - Cambridge Advanced Learner Dictionary. 2nd ed. Cambridge, Cambridge University Press, 2005. $608 \mathrm{p}$.

$L D C E$ - Longman Dictionary of Contemporary English. 3rd ed. Harlow, Longman, 1995. 1670 p.

The Guardian. Available at: http://www. theguardian.com/international.

The Independent. Available at: http:/www. independent.co.uk.

The Observer. Available at: http://www. theguardian.com/observer.

The Times. Available at: http://www. thetimes.co.uk/tto/news.

\section{Information About the Authors}

Tatyana N. Astafurova, Doctor of Sciences (Philology), Professor, Department of Foreign Language Communication, Volgograd State University, Prosp. Universitetsky, 100, 400062 Volgograd, Russian Federation, english@volsu.ru.

Elena S. Aleksandrova, Candidate of Sciences (Philology), Associate Professor, Department of English Philology, Volgograd State University, Prosp. Universitetsky, 100, 400062 Volgograd, Russian Federation, elona1@mail.ru, english_philolog@mail.ru.

\section{Информация об авторах}

Татьяна Николаевна Астафурова, доктор филологических наук, профессор кафедры иноязычной коммуникации, Волгоградский государственный университет, просп. Университетский, 100, 400062 г. Волгоград, Российская Федерация, english@volsu.ru.

Елена Сергеевна Александрова, кандидат филологических наук, доцент кафедры английской филологии, Волгоградский государственный университет, просп. Университетский, 100, 400062 г. Волгоград, Российская Федерация, elona1@mail.ru, english_philolog@mail.ru. 